\author{
Mirosław BISKUP ${ }^{1}$ \\ Juliusz CIEŚLA ${ }^{2}$ \\ Marian SKAWIŃSKI ${ }^{3}$ \\ Lukasz TOPCZEWSKI ${ }^{4}$
}

\title{
AWARIE KABLI SPRĘŻAJĄCYCH W TRAKCIE REALIZACJI BETONOWYCH OBIEKTÓW MOSTOWYCH
}

\begin{abstract}
W artykule przedstawiono dwa typowe przypadki awarii kabli sprężających podczas budowy kablobetonowych obiektów mostowych w Polsce. W obu przypadkach awaria wystąpiła w czasie naciągu kabli. W jej wyniku następował nagły spadek siły naciągu i uszkodzenie betonu w strefie krzywoliniowego przebiegu kabli. Na podstawie analizy dokumentacji, a zwłaszcza rysunków zbrojenia w miejscach uszkodzenia betonu można stwierdzić, że w konstrukcjach nie zastosowano specjalnych prętów zbrojeniowych do przejmowania sił wewnętrznych, wywoływanych przez naciski kabli na odcinkach krzywoliniowych. W miejscach tych, siły nacisku kabla były przenoszone tylko przez beton. Przyjęte rozwiązania były sprzeczne z podstawową zasadą zbrojonego betonu, w którym siły rozciągające powinny być przejmowane przez zbrojenie, a siły ściskające przez beton.
\end{abstract}

Słowa kluczowe: kable sprężające, awarie, mosty betonowe, realizacja

\section{Wstęp}

Dostosowywanie trasy kabli do rozkładu sił wewnętrznych w konstrukcji sprężonej wymaga $\mathrm{w}$ określonych miejscach zmiany kierunku ich działania. W konstrukcjach z kablami wewnętrznymi zmiana przebiegu kabli możliwa jest dzięki ukształtowanym kanałom kablowym w betonie, co zapewnia płynną zmianę kierunku przebiegu i mimośrodu kabli. W konstrukcjach z kablami zewnętrznymi stosuje się zazwyczaj trasy kabli o kształcie wielokąta, a zmiana kierunku działania kabla możliwa jest dzięki dewiatorom usytuowanym w załamaniach trasy, przenoszącym powstające tam dodatkowe siły oddziaływujące na konstrukcję sprężanego przęsła. $\mathrm{W}$ obu przypadkach mamy podobne sytuacje, wynikające

\footnotetext{
${ }^{1}$ Autor do korespondencji/corresponding author: Mirosław Biskup, Instytut Badawczy Dróg i Mostów w Warszawie, tel. (41) 34267 68, e-mail: mbiskup@ibdim.edu.pl

${ }^{2}$ Juliusz Cieśla, Instytut Badawczy Dróg i Mostów w Warszawie

${ }^{3}$ Marian Skawiński, Instytut Badawczy Dróg i Mostów w Warszawie

${ }^{4}$ Łukasz Topczewski, Instytut Badawczy Dróg i Mostów w Warszawie
} 
z konieczności przeniesienia sił powstających w miejscach zmiany kierunku działania kabla sprężającego i działających prostopadle do jego osi. Podobieństwo wynika stąd, że w obu przypadkach zmianę kierunku kabla dokonujemy $\mathrm{z}$ zachowaniem pewnego promienia, zalecanego przez producenta systemu sprężania i zmiany tej dokonuje się $\mathrm{w}$ obrębie przekroju betonowego dźwigara lub dewiatora. W obu przypadkach na krzywoliniowym odcinku kabla powstają siły prostopadłe do jego osi, które przekazywane są na wewnętrzną powierzchnię betonu w stosunku do jego krzywizny. Siły te, wyrażone w jednostce siły przypadającej na jednostkę długości kabla np. MN/m o kierunku radialnym, można przedstawić za pomocą wzoru opartego na zasadzie przyjętej przez Eulera o postaci:

$$
q_{z}=\frac{P_{v} * \gamma_{P}}{r}
$$

w którym: $P_{v}$ - siła sprężająca dla pojedynczego kabla sprężającego,

$r$ - promień krzywizny kabla,

$\gamma_{P}$ - częściowy współczynnik bezpieczeństwa dla siły sprężającej wg aktualnej normy.

W konsekwencji projektant musi uwzględnić fakt, że na określonej długości łuku s działa na element betonowy siła o łącznej wartości:

$$
F_{r}=\int_{0}^{s} q_{z} d s,
$$

Siła ta, działająca prostopadle do kierunku sprężenia, wywołuje naprężenia rozciągające w betonie, które mogą spowodować zniszczenie fragmentu konstrukcji i zwolnienie naciągu kabla sprężającego, o ile naprężenia te nie zostaną w odpowiedni sposób przeniesione [1]. W Eurokodach PN EN 1992-1-1 i PN EN 1992-2 [2,3] stwierdza się jedynie ogólnikowo, że dewiator powinien przenieść zarówno siły podłużne jak i poprzeczne, które przekazuje na niego cięgno oraz zapewnić, że promień krzywizny cięgna nie spowoduje jakiegokolwiek przekroczenia naprężeń lub jego uszkodzenia. Nie podaje jednak konkretnego sposobu przeniesienia powstających na krzywiźnie kabla sił radialnych. Nie wszyscy projektanci poświęcają należytą uwagę tym zjawiskom, dlatego zdarzają się błędy projektowe, które skutkują awarią w czasie sprężania obiektu. Usunięcie awarii często bywa kłopotliwe i kosztowne.

Przykłady takich problemów można znaleźć zarówno w kraju, jak i za granicą. W artykule [4], opisano przypadek awarii, która miła miejsce w czasie sprężania trzyprzęsłowego kablobetonowego mostu o przekroju skrzynkowym w Chinach. W trakcie naciągu kabli sprężających nastąpiło rozerwanie płyty dolnej przekroju skrzynkowego. Autorzy powyższego artykułu, jako przyczynę tego zjawiska podają między innymi brak odpowiedniego zbrojenia, które mogłoby przejąć naprężenia rozciągające $\mathrm{w}$ betonie. $\mathrm{W}$ artykule tym wspomniano również, że takie awarie kilkakrotnie miały tam miejsce w ciągu ostatnich lat. 
Krajowym przykładem awarii o podobnym charakterze może być budowa mostu w ciągu autostrady A1 w Mszanie, gdzie w trakcie budowy również nastąpiła awaria dolnej płyty kablobetonowego dźwigara skrzynkowego, polegająca na jej rozwarstwieniu. Profesor J. Biliszczuk w swoim referacie [5] wskazuje przyczyny tej awarii, przypisując ją siłom powstałym w wyniku krzywizny płyty i imperfekcji wykonawczych kabli, wobec braku należytego powiązania górnej i dolnej siatki zbrojeniowej płyty. Autor wymienia również kilka innych podobnych awarii, w których wystąpiły uszkodzenia płyty dolnej kablobetonowych dźwigarów skrzynkowych z tych samych powodów.

Przedstawione przykłady awarii wskazują, że niekorzystne oddziaływania na konstrukcję sił radialnych wywoływane przez kable sprężające, mogą być zarówno wynikiem niedoceniania tych zjawisk przez projektantów, jak również błędów i niedokładności wykonawczych.

W niniejszym artykule opisano dwa typowe przypadki awarii kabli w trakcie budowy obiektów mostowych z betonu sprężonego w Polsce, które były szczegółowo analizowane przez autorów.

\section{Awaria kabla sprężającego estakady w węźle Ostrobramska - Marsa w Warszawie}

Ustrój niosący estakady zaprojektowano jako pięcioprzęsłową konstrukcję ciągła, o przekroju skrzynkowym o rozpiętościach teoretycznych poszczególnych przęseł: $38,00+38,96+38,95+44,98+35,00 \mathrm{~m}$ i całkowitej długości 195,90 m [1]. W przekroju poprzecznym konstrukcja niosąca posiada kształt jednokomorowej skrzynki z obustronnymi wspornikami w przęsłach i w strefach podporowych, o stałej wysokości konstrukcyjnej około 1,90 m. Przekrój skrzynkowy usztywniono poprzecznicami podporowymi. Konstrukcję niosącą zaprojektowano jako kablobetonową, sprężoną kablami 25L15,7, wykonaną z betonu B50, który odpowiada klasie betonu C40/50 według aktualnych oznaczeń. Estakadę zaprojektowano na obciążenie klasy A wg PN-85/S-10030 [6]. W każdym ze środników zastosowano po 4 kable o trasie parabolicznej, biegnące wzdłuż całej estakady, łączone w przęśle II w styku konstrukcyjnym. Oprócz tego nad podporami pośrednimi zastosowano prostoliniowe kable odcinkowe, kotwione obustronnie po uprzednim odgięciu ku dołowi, w blokach kotwiących, usytuowanych w wewnętrznych narożach przekrojów skrzynkowych.

Na rys. 1 pokazano przekrój poprzeczny, a na rys. 2 przekrój podłużny przęsła nad podporą 5 , w strefie gdzie wystąpiła awaria. Na rysunkach tych pokazano trasę kabla odcinkowego $\mathrm{nr} 22$ nad podporą 5, który uległ awarii.

Awaria nastąpiła w czasie naciągu kabla nr 22 i polegała na nagłym odspojeniu się betonu, stanowiącego otulinę w jego krzywoliniowej części w sąsiedztwie podpory 5, obok bloku kotwiącego tego kabla [1]. Obszar zniszczenia struktury betonu był dosyć znaczny i wyniósł około 1,8 m wzdłuż przęsła i około $0,9 \mathrm{~m}$ w poprzek przęsła. Zniszczoną strefę betonu bezpośrednio po awarii pokazano na rys. 3 . 


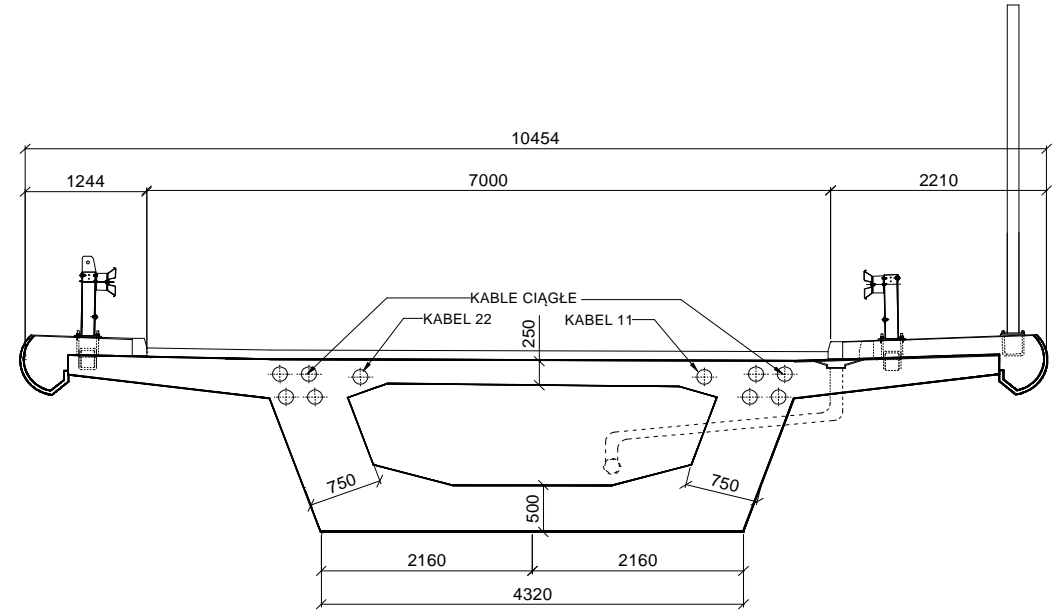

Rys. 1. Przekrój poprzeczny przęsła nad podporą 5

Fig. 1. The cross-section of the span over the support 5

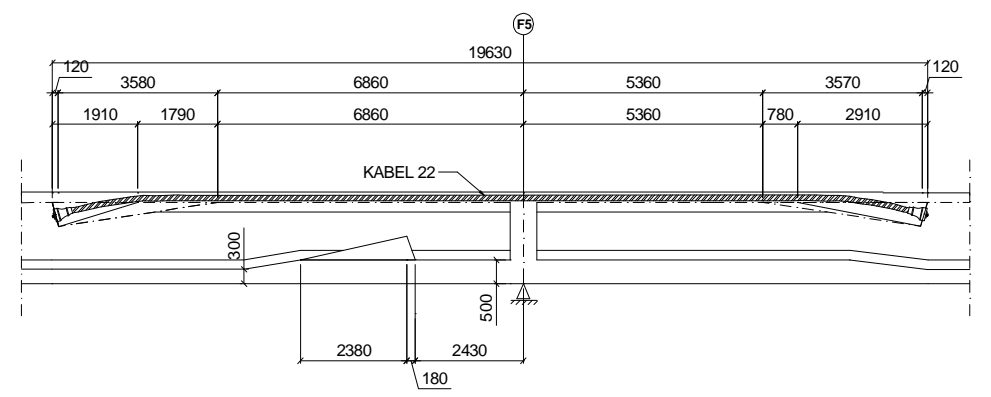

Rys. 2. Przekrój podłużny przęsła nad podporą 5

Fig. 2. Longitudinal section of the span over the support 5

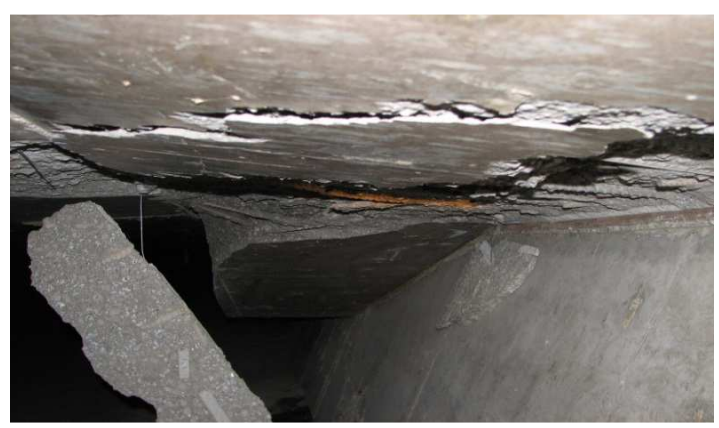

Rys. 3. Widok górnej płyty skrzynki bezpośrednio po awarii

Fig. 3. View of the top plate of the box girder immediately after the crash 
Na podstawie dokonanych oględzin można było stwierdzić, że minimalna otulina kabla wynosiła tylko około $8 \mathrm{~cm}$. Po zwolnieniu kabla nr 22 stwierdzono również rysy na bloku kotwiącym i płycie w strefie odgięcia kabla nr 11, położonego po drugiej stronie skrzynki w stosunku do miejsca awarii kabla nr 22. W miejscu tym nie stwierdzono jednak większego uszkodzenia strefy betonu otulającej kabel. Uszkodzeń w pozostałych strefach odgięć kabli nad podporowych nie stwierdzono.

Ze względu na lokalny charakter awarii, bardziej szczegółowej analizie poddano strefy odgięć odcinkowych kabli nad podporowych. Na podstawie przeglądu dokumentacji, a zwłaszcza rysunków tych stref, można stwierdzić, że w projekcie nie zastosowano zbrojenia do przeniesienia sił wywołanych dociskiem, występującym na wewnętrznej krzywiźnie kabla i w związku z tym wynikające $\mathrm{z}$ tego oddziaływania przenoszone są wyłącznie przez beton. Jest to sprzeczne z kardynalną zasadą, przyjmowaną żelbecie, że siły wywołujące rozciąganie powinny być przenoszone przez zbrojenie, a beton powinien pracować wyłącznie na ściskanie. W konsekwencji nośność tej strefy zależy od wytrzymałości betonu na rozciąganie i od grubości otuliny. W rezultacie konstrukcja jest bardzo wrażliwa na niedokładności wynikające $\mathrm{w}$ trakcie wykonawstwa, na przykład zmniejszenie grubości otuliny powoduje proporcjonalne obniżenie nośności tej strefy.

W celu określenia przyczyn awarii przeprowadzono przybliżone obliczenia sprawdzające dla stref, w których wystąpiła awaria. Obliczenia te wykonano dla dwóch przypadków, a mianowicie:

- ułożenie kabla i kształt deskowania tej strefy są zgodne z projektem,

- ułożenie kabla i kształt deskowania są zgodne ze stanem stwierdzonym na budowie.

Przyjęto przy tym, że zniszczenie następuje na skutek nacisku kabla na jego krzywiźnie na beton, poprzez wyrwanie klina odłamu betonu pod kątem $45^{\circ}$ (rys. 4).

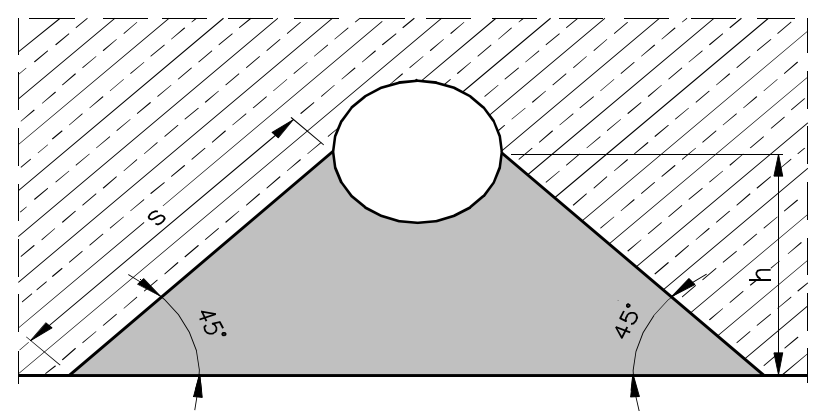

Rys. 4. Schemat zniszczenia strefy betonu pod kablem

Fig. 4. Scheme of the destruction of the concrete area under the cable

Obliczony według wzoru (1) nacisk kabla na beton, przy przyjętym w projekcie promieniu krzywizny $\mathrm{r}=6,0 \mathrm{~m}$, wyniósł $\mathrm{q}_{\mathrm{z}}=1,060 \mathrm{MN} / \mathrm{m}$. Szerokość przełomu 2 s określić można z zależności geometrycznych, przyjmując wymiary kabla i otuliny z projektu. Stąd $\mathrm{h}=22,0+6,0=28,0 \mathrm{~cm}$, a połowa szerokości przełomu: 
$s=\sqrt{2 * 28,0^{2}}=39,6 \mathrm{~cm}$

oraz średnie naprężenia rozciągające na powierzchni przełomu wyniosą:

$$
\sigma=\frac{q_{z}}{2 * s * 1,0}=\frac{1.0602}{2 * 0,396 * 1,0}=1,34 \mathrm{MPa}<R_{b t 0,05}=1,60 \mathrm{MPa},
$$

Wynika z tego, że naprężenia rozciągające na powierzchni przełomu osiągają $84 \%$ wytrzymałości obliczeniowej betonu zbrojonego $\mathrm{B} 50$ na rozciąganie $\mathrm{R}_{\mathrm{bt} 0,05}$ oraz są większe od wytrzymałości betonu niezbrojonego $\mathrm{R}_{\mathrm{bbto}, 50}=1,20 \mathrm{MPa}$ wg. PN-91/S-10042 [7]. Normy europejskie PN-EN 1992-1-1 [2] oraz PN-EN 1992-2 [3] nie podają wytrzymałości betonu niezbrojonego na rozciąganie. Norma PN-EN 1992-2 podaje jedynie wzór na określenie wytrzymałości obliczeniowej betonu na rozciąganie:

$$
f_{c t d}=\alpha_{c t} * f_{c t k 0,05} / \gamma_{c}
$$

w którym: - $f_{c t k o, 05}$ - wytrzymałość charakterystyczna betonu na rozciąganie,

- $\gamma_{c}$ - materiałowy współczynnik bezpieczeństwa dla betonu równy 1,5 ,

- $\alpha_{c t}$ - współczynnik redukcyjny o zalecanej wartości od 0,8 do 1,0 o ile załącznik krajowy nie podaje innej wartości.

Ponieważ w opisywanym przypadku brak jest zbrojenia do przeniesienia naprężeń rozciągających w betonie pod wpływem nacisku kabli na krzywiźnie uznano za stosowne przyjęcie wartości $\alpha_{c t}=0,8$. Wytrzymałość obliczeniowa betonu $\mathrm{C} 40 / 50$ na rozciąganie wynosi w tym przypadku $f_{c t d}=1,33 \mathrm{MPa}$, czyli jest $\mathrm{w}$ przybliżeniu równa wartości naprężeń obliczonych według wzoru (3).

$\mathrm{Z}$ powyższego wynika, że średnie naprężenia $\mathrm{w}$ betonie, nawet przy zachowaniu wymiarów przyjętych w projekcie, są równe lub większe od wartości wytrzymałości obliczeniowej betonu na rozciąganie.

Podobnie określone naprężenia rozciągające, dla stwierdzonej na budowie otuliny kabla 22 o grubości $8,0 \mathrm{~cm}$, wyniosły aż $2,68 \mathrm{MPa}$, czyli w przypadku tym wartość ta przekroczyła około dwukrotnie wartość wytrzymałości obliczeniowej betonu na rozciąganie, co tłumaczy przyczynę wystąpienia awarii.

Powyższe wyliczenia potwierdzają fakt, że otulina betonowa kabla znajduje się w stanie krytycznym i przy jakichkolwiek niedokładnościach w jego ułożeniu naprężenia w betonie mogą przekroczyć wartości dozwolone i doprowadzić do awarii. Na podstawie dokonanych analiz, podjęto decyzję o wzmocnieniu wszystkich strefy odgięć kabli nad podporowych.

- strefy odgięć kabli, które nie zostały jeszcze zabetonowane można było wzmocnić przez zastosowanie odpowiedniego zbrojenia dodatkowego, które mogły przenieść promieniowy nacisk tych kabli na beton na ich krzywoliniowych odcinkach.

- strefę odgięcia kabla 22, w pobliżu podpory 5, gdzie nastąpiła awaria oraz strefy odgięć pozostałych kabli nad podporowych, wzmocniono przez zaprojektowa- 
nie podpór żelbetowych w kształcie pilastrów, obejmujących w planie uszkodzone strefy płyty górnej przekroju skrzynkowego.

\section{Awaria na wiadukcie nad linią kolejową w Tarnawie Dolnej}

Wiadukt zlokalizowany jest $\mathrm{w}$ ciągu nowo projektowanego odcinka drogi krajowej nr 28 Wadowice - Sucha Beskidzka, na odcinku Tarnawa Dolna - Zembrzyce nad linią kolejową Stryszów - Sucha Beskidzka. Obiekt przeznaczony jest do bezkolizyjnego przeprowadzenia ruchu drogowego nad istniejącą i projektowaną linią kolejową. Inwestycja wykonywana jest w ramach zadania budowy zbiornika Świnna Poręba.

Wiadukt zaprojektowano jako konstrukcję kablobetonową, czteroprzęsłową ciągłą, położoną w łuku. Konstrukcja niosąca wiaduktu to dźwigar skrzynkowy o rozpiętościach poszczególnych przęseł wynoszącą:

$39,00+47,50+47,50+39,00 \mathrm{~m}$. Szerokość jezdni wynosi 7,00+2 x 0,50 m z obustronnymi chodnikami o szerokości 2,00 m. Całkowita długość w osi obiektu wynosi 195,62 m, natomiast całkowita szerokość prostopadle do osi obiektu wynosi $13,10 \mathrm{~m}$. Konstrukcję przęseł wiaduktu wykonano z betonu klasy C35/45 według oznaczeń zgodnych z PN-EN 1992-1-1 [2].

Konstrukcja niosąca została sprężona łącznie 24 kablami zewnętrznymi składającymi się z lin $\varnothing 15,5 \mathrm{~mm}$ :

- BBR VT CONA CME 1906 - 1501860 o początkowej sile naciągu 3,975 MN,

- BBR VT CONA CME 1506 - 1501860 o początkowej sile naciągu 3,140 MN,

- BBR VT CONA CME 0706 - 1501860 o początkowej sile naciągu 1,465 MN.

W obliczeniach oddziaływania kabli na konstrukcję uwzględniono doraźne i reologiczne straty siły sprężającej oraz współczynnik obciążeń $\gamma_{\mathrm{p}}$, który wynosi 1,2 lub 0,85, w zależności od tego, czy siła sprężająca dzieła obciążająco, czy odciążająco. Przekrój poprzeczny przęsła z dewiatorem przedstawiono na rysunku 5, natomiast schemat układu dewiatorów oraz kabli w przekroju podłużnym przęsła 1-2 pokazano na rysunku 6.

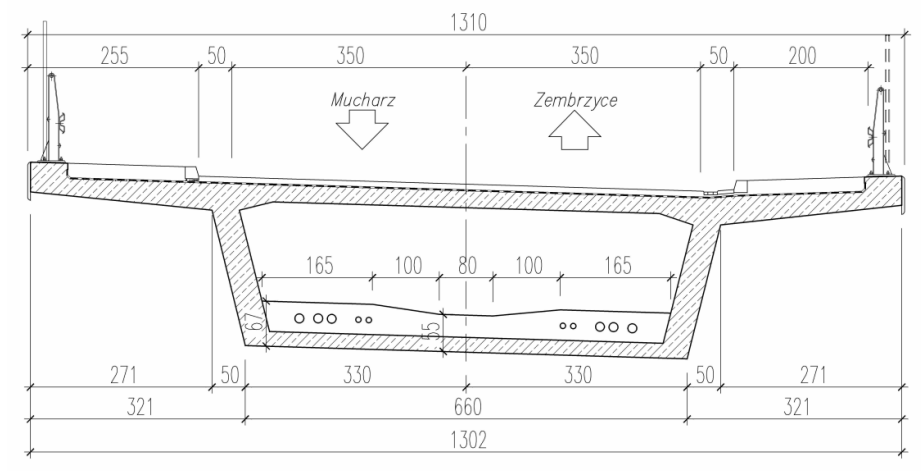

Rys. 5. Przekrój poprzeczny przęsła z dewiatorem

Fig. 5. The cross-section of the span at the deviator 


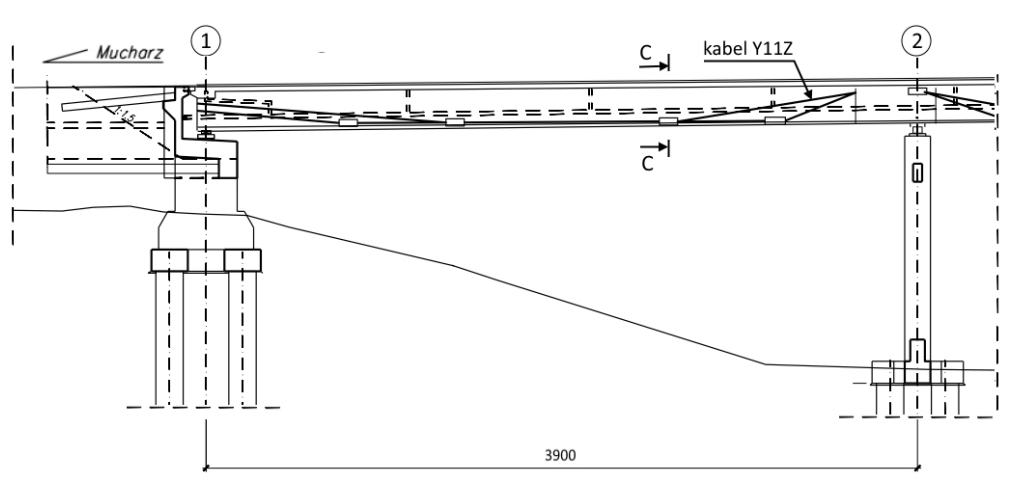

Rys. 6. Przekrój podłużny przęsła z dewiatorami

Fig. 6. Longitudinal section of the span with deviators

Awaria miała miejsce $\mathrm{w}$ trakcie naciągu kabla $\mathrm{Y} 11 \mathrm{Z}$ w dewiatorze $\mathrm{w}$ przekroju C-C przęsła 1-2. W rezultacie nastąpiło oderwanie fragmentu betonu dewiatora bezpośrednio nad kablem sprężającym (Rys. 7). Po awarii naciąg kabla został zwolniony.

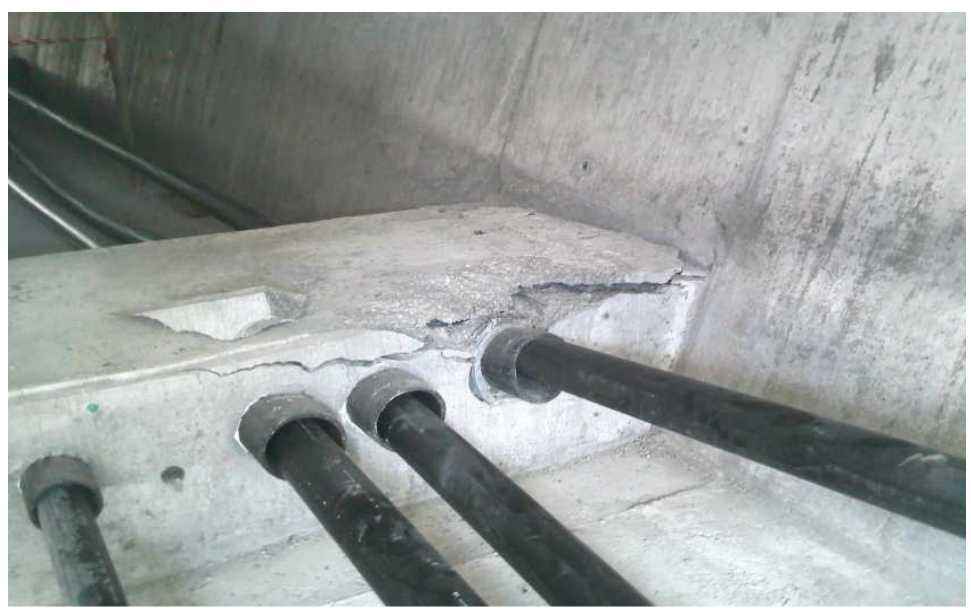

Rys. 7. Widok zniszczonego fragmentu dewiatora

Fig. 7. View of the damaged part of the deviator

Wnioski dotyczące przyczyn zaistniałej awarii nasuwają się już po pobieżnej analizie dokumentacji projektowej oraz analizie zaistniałych uszkodzeń. Dlatego też, zakres obliczeń sprawdzających ograniczono do przedstawienia w sposób uproszczony naprężeń rozciągających w betonie poszczególnych dewiatorów obciążonych wypadkową siły naciągu kabli.

Obliczenia sprawdzające dewiatorów w przęsłach 1-2 i 2-3 przeprowadzono na podstawie elementarnych założeń, umożliwiających określenie średnich warto- 
ści naprężeń rozciągających w betonie, powstających w miejscach odgięcia kabli sprężających.

Przyjęto hipotetyczne założenie, że zniszczenie dewiatora następuje na skutek docisku kabli do betonu na ich krzywiźnie o natężeniu $q_{z}$ (por. pkt. 1). Wypadkowa tego obciążenia wywołuje naprężenia rozciągające $\mathrm{w}$ betonie, które w konsekwencji powodują oddzielanie się klina odłamu betonu w dewiatorze pod kątem $45^{\circ}$. Na rys. 8 i 9 przedstawiono widok klina odłamu betonu dla przypadku dwóch kabli odgiętych w dewiatorze.

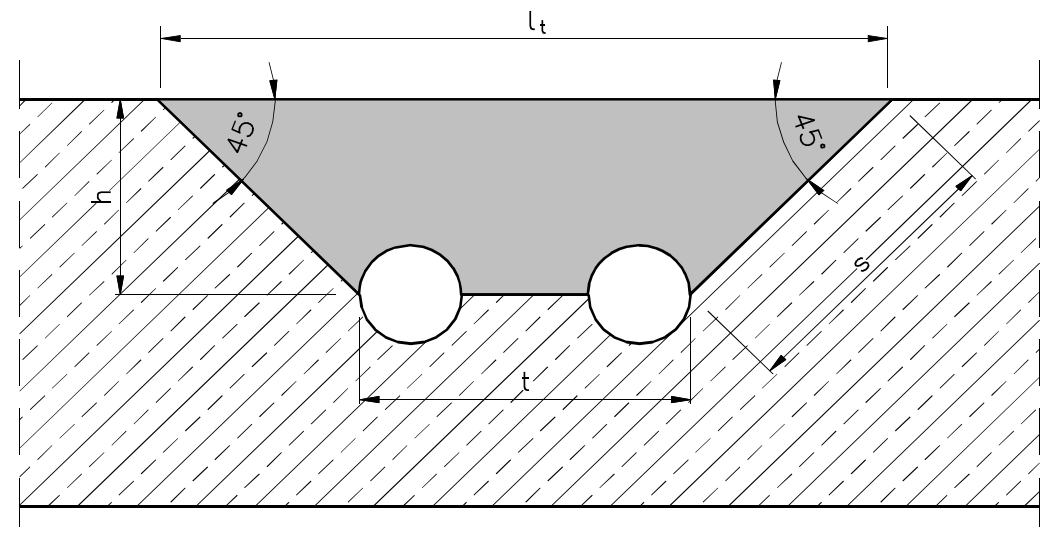

Rys. 8. Klin odłamu betonu w poprzek kabli

Fig. 8. Scheme of the destruction of the concrete area across the cables

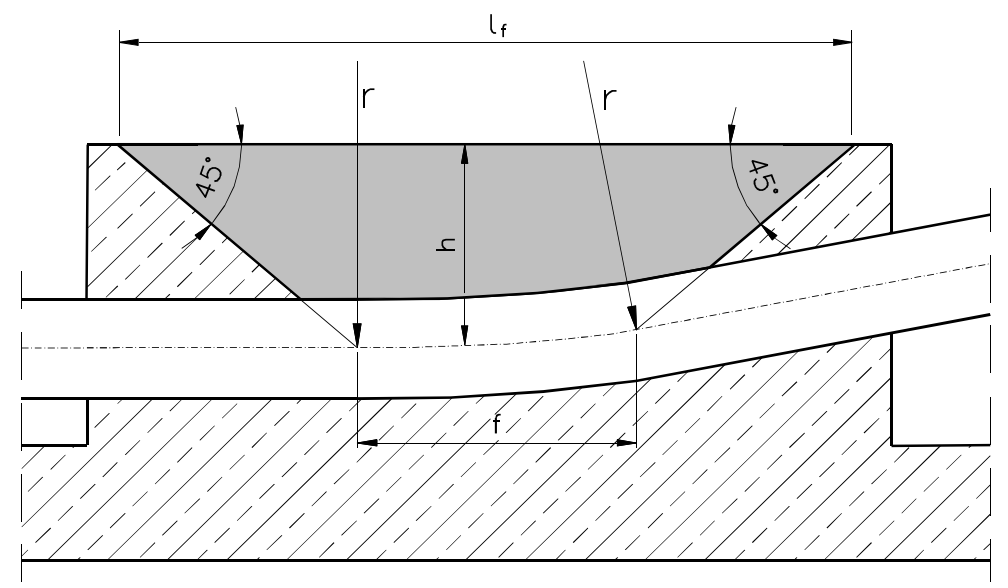

Rys. 9. Klin odłamu betonu wzdłuż kabli

Fig. 9. Scheme of the destruction of the concrete area along the cables

Wartość docisku poprzecznego kabli na beton $q_{z}$ na ich krzywiźnie wyznaczono ze wzoru (1). Wartość częściowego współczynnika $\gamma_{P}$ przyjęto równą 1 , ponieważ jako siły sprężające przyjęto ich wartości początkowe, czyli możliwie 
największe, kontrolowane do tego w trakcie procesu sprężania. Przyjęto, że docisk ten będzie się realizował na całej długości łuku, którą można przyjąć równą długości siecznej $f$, czyli całkowita wartość siły rozciągającej beton w dewiatorze będzie wynosić: $F_{r}=q * f[\mathrm{MN}]$. Siła ta, wobec braku skutecznego zbrojenia w kierunku jej działania, będzie wywoływała naprężenia rozciągające w betonie dewiatora. Powierzchnia, na którą rozkłada się ta siła, to powierzchnia klina odłamu betonu w kształcie ściętego ostrosłupa. Ostatecznie na podstawie zależności geometrycznych przyjęto, że siła $F_{r}$ będzie się rozkładała na hipotetycznej powierzchni zniszczenia, wywołując naprężenia rozciągające o wartości:

$$
\sigma=\frac{F_{r}}{t \times f+s\left(t+l_{f}+f+l_{t}\right)}
$$

W obliczeniach uwzględniono rzeczywistą liczbę odginanych kabli w danym dewiatorze. Obliczone w ten sposób naprężenia $\sigma$ są wartościami średnimi. Miejscowe naprężenia rozciągające mogą znacznie przekraczać te wartości. Obliczenia przeprowadzono dla wszystkich grup kabli i dewiatorów.

Na podstawie dokonanych obliczeń uzyskano następujące wartości naprężeń rozciągających w betonie:

- dla projektowanego położenia kabli sprężających, maksymalna wartość naprężeń wynosi 1,75 MPa, a średnia 1,13 MPa,

- dla rzeczywistego położenia kabli sprężających, wynikającego z błędów wykonawczych, obliczona maksymalna wartość naprężeń wynosi 2,32 MPa, a średnia 1,23 MPa,

- w dewiatorze w którym nastąpiła awaria wartość naprężeń wynosiła 1,57 MPa,

Obliczone średnie wartości naprężeń są bliskie wytrzymałości obliczeniowej betonu niezbrojonego B45 na rozciąganie według normy [7], wynoszącej $\mathrm{R}_{\mathrm{bbt}}=1,15 \mathrm{MPa}$ oraz betonu C35/45 według normy PN-EN 1992-2 [3] , wynoszącej $\mathrm{f}_{\text {ctd }}=1,17 \mathrm{MPa}$ przy projektowanym położeniu kabli, a przy położeniu rzeczywistym je przekraczają. Natomiast wartość naprężeń w dewiatorze, w którym nastąpiła awaria oraz obliczone maksymalne wartości naprężeń znacznie przekraczają wartości wytrzymałości obliczeniowych. Wyjaśnia to przyczynę awarii naciąganego kabla Y11Z w dewiatorze C-C. Ryzyko awarii jest o tyle większe, o ile uwzględnimy możliwość występowania miejscowej koncentracji naprężeń.

Elementem dodatkowym, który bez wątpienia wpłynął na skalę awarii dewiatora $\mathrm{C}-\mathrm{C}$, to błędy wykonawcze, popełnione podczas tyczenia tras kabli.

Analizując dokumentację projektową obiektu, nasuwa się od razu istotne spostrzeżenie, że w dewiatorach nie przewidziano zbrojenia, które skutecznie może przejąć naprężenia rozciągające w betonie, spowodowane działaniem wypadkowych sił naciągu kabli. Zastosowane w dewiatorach zbrojenie w postaci strzemion nie może przenieść naprężeń w wymaganym kierunku, co sprawia, że beton zachowuje się jak niezbrojony. Elementarną zasadą powinno być stosowanie specjalnych prętów zszywających, przeciwdziałających rozwarstwieniu się betonu, 
ewentualnie przepon, które przeniosłyby siły powodujące rozciąganie w betonie. Wytrzymałość betonu na rozciąganie powinna być traktowana jedynie jako rezerwa, a nie podstawowy element zapewniający nośność dewiatora.

\section{Wnioski końcowe}

Z przeprowadzonej analizy obliczeniowej awarii kabla sprężającego estakady w węźle Ostrobramska - Marsa w Warszawie wynika że:

- nie zastosowano zbrojenia do przeniesienia naprężeń rozciągających w betonie, powodowanych naciskiem kabli na beton na krzywiznach,

- otulina betonowa, przy idealnym zachowaniu trasy kabli nad podporowych na łuku i geometrii konstrukcji w tej strefie zgodnie z projektem, znajduje się blisko granicznej wartości, jaką może wytrzymać beton w stanie rozciągania,

- przy niedokładnościach w ułożeniu kabli naprężenia w betonie przekroczyły wartości dopuszczalne i to doprowadziło to do awarii, jaka miała miejsce w opisywanym przypadku.

Na podstawie przytoczonego materiału $\mathrm{z}$ awarii wiaduktu w Tarnawie można sformułować następujące wnioski:

- podstawową przyczyną awarii, tak jak i w przypadku estakady w węźle Ostrobramska - Marsa, był brak odpowiedniego zbrojenia w strefie naprężeń rozciągających w betonie dewiatorów,

- w projekcie należało zastosować strzemiona pętlowe, przenoszące siły rozciągające, lub odpowiednio ukształtowane przepony, które wyeliminowałby prawie całkowicie rozciąganie, a jednocześnie wzmocniłyby dewiatory w pracy na zginanie poprzez zmniejszenie ich rozpiętości,

- skala uszkodzenia dewiatora C-C, spowodowana była również niezgodnym z projektem trasowaniem kabli przez wykonawcę.

$\mathrm{Z}$ analizy dokumentacji projektowej obu obiektów, nasuwa się istotne spostrzeżenie, że nie przewidziano w nich zbrojenia, które mogłoby przejąć skutecznie naprężenia rozciągające $w$ betonie, spowodowane działaniem radialnych sił powstających na krzywiznach kabli. Przyczyny opisywanych przypadków rozwarstwiania się dolnych płyt przekrojów skrzynkowych pod wpływem sprężenia osiowego są podobne i wynikają najprawdopodobniej z powstających na skutek imperfekcji wykonawczych krzywizn kabli, które generują naprężenia rozciągające w betonie.

\section{Literatura}

[1] J. Cieśla, K. Fordoński: Awaria kabla sprężającego i projekt naprawy estakady w węźle Ostrobramska w Warszawie; Drogownictwo nr 12/2007.

[2] PN EN 1992-1-1 Eurokod 2 - Projektowanie konstrukcji z betonu. Część 1-1: Reguły ogólne dla budynków.

[3] PN EN 1992-2 Eurokod 2 - Projektowanie konstrukcji z betonu. Część 2: Mosty betonowe. Projektowanie i szczegółowe zasady. 
[4] Xin Ruan, Xuefei Shi, Xiaoxiang Li, Failure analysis of tendon on bottom slab of a prestressed concrete box gird bridge during construction; Engineering Failure Analysis 25 (2012) 291-303.

[5] J. Biliszczuk, Most MA 532 w ciągu autostrady A1 w Mszanie. Historia budowy; Wrocławskie Dni Mostowe, Wrocław, 21-22 listopada 2013.

[6] PN-85 / S-10030 Obiekty mostowe. Obciążenia.

[7] PN-91/S-10042 Obiekty mostowe. Konstrukcje betonowe, żelbetowe i sprężone. Projektowanie.

\section{FAILURES OF PRESTRESSING CABLES DURING EXECUTION OF CONCRETE BRIDGES}

\section{S u m m a r y}

The paper describes two typical cases of failure of prestressing cables during construction of concrete bridges in Poland. In both cases failures occurred at the time of tension of the cables, and consisted of sudden loosening of cables and failure of concrete in zone under the curved portion of the cables. Based on the review of documentation, and particularly of the drawings of these zones, it can be concluded, that in the design were not applied of the special reinforcement bars for overtaking the forces caused by the pressure occurring on the inner curvature of the cables, and the resulting forces are transferred only by the concrete. The basic principle of reinforced concrete is, that tensile forces should be taken by reinforcement, and the compressive forces by the concrete.

Keywords: prestressing cables, failures, concrete bridges, execution

Przestano do redakcji: 07.06.2016 $r$.

Przyjęto do druku: 30.06.2016 r.

DOI: $10.7862 / \mathrm{rb} .2016 .101$ 